\title{
Isolated intraductal variant of hepatocellular carcinoma
}

\author{
Cyriac Abby Philips, ${ }_{1}^{1}$ Rajaguru Paramaguru, ${ }^{2}$ Pushpa Mahadevan, ${ }^{3}$ Philip Augustine ${ }^{4}$
}

'Department of Hepatology and Transplant Medicine, PVS Memorial Hospital Ltd, Cochin, Kerala, India

2Department of Pathology, PVS Memorial Hospital Ltd, Cochin, Kerala, India

${ }^{3}$ Department of Pathology, Lakeshore Hospital and Research Centre Ltd, Cochin, Kerala, India

${ }^{4}$ Department of

Gastroenterology, PVS Memorial Hospital Ltd, Cochin, Kerala, India

\section{Correspondence to}

Dr Cyriac Abby Philips, abbyphilips@gmail.com

Accepted 1 August 2017 CrossMark

\section{To cite: Philips CA,} Paramaguru R, Mahadevan $P_{\text {, }}$ et al. BMJ Case Rep Published Online First: [please include Day Month Year]. doi:10.1136/bcr-2017 221324

\section{DESCRIPTION}

A 70-year-old male teetotaller, with a history of chronic obstructive lung disease and hypertension, presented to the emergency department with a 2-day history of right upper quadrant pain and melaena. Investigations revealed total bilirubin $6.8 \mathrm{mg} / \mathrm{dL}$, aspartate and alanine transaminases 88 and $122 \mathrm{IU} / \mathrm{L}$, respectively, alkaline phosphatase $338 \mathrm{IU} / \mathrm{L}$ and gamma-glutamyl transpeptidase 223 IU/L. Tests for chronic hepatitis B, hepatitis C and HIV were negative. Serum alpha-fetoprotein was $22.8 \mathrm{ng} / \mathrm{mL}$, whereas carcino-embryonic antigen (CEA), CA 19-9, prostate specific antigen and chromogranin levels were normal. Contrast CT of the abdomen revealed fatty liver with moderate dilation of bilateral intrahepatic biliary radicles (figure 1A) and dilated common bile duct (CBD) with hyperdense contents, without identifiable mass lesions in the liver or biliary tree. Upper gastrointestinal endoscopy revealed haemobilia, and cholangiogram showed normal calibre CBD with filling defects. Endoscopic intraductal ultrasound revealed focal thickening of segment three hepatic duct, and Spyglass cholangioscopy confirmed a white polypoidal lesion (figure 1B, black arrow) with abnormal surface vessels (figure $1 \mathrm{~B}$, white arrow) and few blood clots. Histopathology revealed few ductal cells with reactive atypia and streams of epithelial cells forming columns among vascular channels

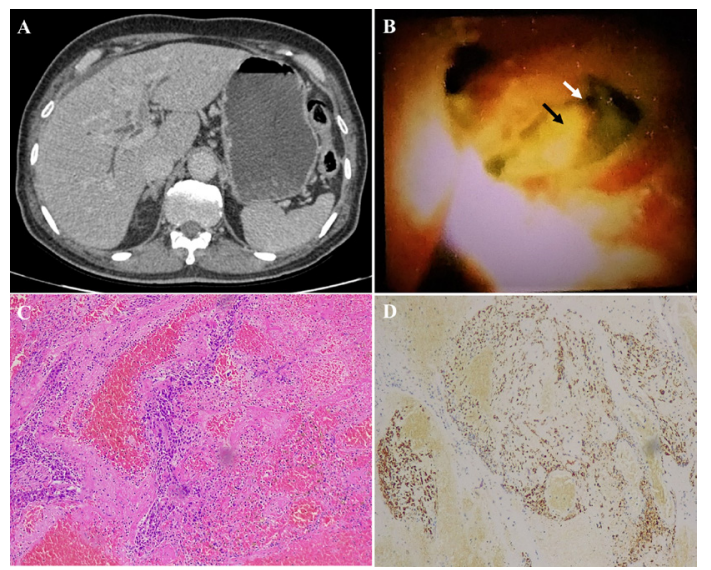

Figure 1 (A) Contrast CT of the abdomen showing dilation of intrahepatic biliary radicles without identifiable mass lesions in the liver or biliary tree. (B) Spyglass cholangioscopy of the biliary tree showing a polypoidal lesion in segment three bile duct. (C) Histopathology from the polypoidal lesion showing streams of epithelial cells forming columns and showing variation in nuclear size. (D) Immunohistochemistry of the intraductal lesion showing hepatocyte antibody positivity. exhibiting mild variation in nuclear size (figure 1C). Immunohistochemistry showed pancytokeratin and hepatocyte antibody positive cells (figure 1D) lining vascular spaces that were negative for CD34, CK 7, CK 20, synaptophysin and chromogranin and exhibited high proliferation index, suggestive of hepatocellular carcinoma (HCC) of isolated intraductal type. Surgical options and palliation with biliary stenting and addition of sorafenib were suggested, the family opting for the latter. Eight weeks after stenting and initiation of sorafenib, liver functions normalised, while clinically, mild anorexia persisted.

We describe a patient with HCC, presenting as isolated intraductal mass in the absence of parenchymal mass lesions, tumour extension into the biliary tree or pure bile duct thrombus.

The earliest description of HCC of bile ducts without palpable surface liver mass on laparotomy was described by Sanford in $1952 .{ }^{1}$ Thereafter, rare reports of such presentations were documented in the literature. In most cases, the liver was cirrhotic, and parenchymal lesions were identified on follow-up imaging. In all cases, the mass involved the extrahepatic bile ducts. ${ }^{2}$ Our case is novel because HCC developed within intrahepatic bile ducts in a non-cirrhotic liver. Tsushimi et al hypothesised that HCC arising within bile ducts was from ectopic liver tissue. ${ }^{3}$ We believe that ectopic theory along with epigenetic and genetic factors in the background of non-alcoholic fatty liver disease brings about variations in morphological and biological characteristics in HCC.

Learning points

- Presentation of hepatocellular carcinoma as an isolated intrahepatic intraductal mass in a non-cirrhotic liver has not been described before.

- In intraductal hepatocellular carcinoma, parenchymal lesions usually develop on follow-up imaging.

- Biopsy of biliary mass lesions presenting atypically, in cirrhotic or non-cirrhotic liver, could help in ideal treatment decision.

- Hepatocellular carcinoma must be kept as a differential diagnosis of isolated biliary mass lesions.

Contributors CAP designed the study and wrote the manuscript. RP and PM provided pertinent clinical images for the study. PA revised the manuscript and provided pertinent changes. All authors finalised the manuscript. 
Competing interests None declared.

\section{Patient consent Obtained.}

Provenance and peer review Not commissioned; externally peer reviewed.

(C) BMJ Publishing Group Ltd (unless otherwise stated in the text of the article) 2017. All rights reserved. No commercial use is permitted unless otherwise expressly granted.

\section{REFERENCES}

1 Sanford CH. Primary malignant disease of the liver. Ann Intern Med 1952:37:304-12.

2 Seriau L, Leo CA, Girometti R, et al. Hepatocellular carcinoma presenting as bile duct tumor: a case report. J Gastrointest Cancer 2014;45(Suppl 1):103-7.

3 Tsushimi T, Enoki T, Harada E, et al. Ectopic hepatocellular carcinoma arising in the bile duct. J Hepatobiliary Pancreat Surg 2005;12:266-8.

Copyright 2017 BMJ Publishing Group. All rights reserved. For permission to reuse any of this content visit http://group.bmj.com/group/rights-licensing/permissions.

BMJ Case Report Fellows may re-use this article for personal use and teaching without any further permission.

Become a Fellow of BMJ Case Reports today and you can:

- Submit as many cases as you like

- Enjoy fast sympathetic peer review and rapid publication of accepted articles

Access all the published articles

Re-use any of the published material for personal use and teaching without further permission

For information on Institutional Fellowships contact consortiasales@bmjgroup.com

Visit casereports.bmj.com for more articles like this and to become a Fellow 